\title{
Transaction Cost for Salt Farmers in Pesanggrahan Village, Kwanyar District, Bangkalan Regency
}

\author{
BUDI SASONGKO ${ }^{1}$, ENY LESTARI WIDARNI ${ }^{2}$, SURYANING BAWONO ${ }^{3}$ \\ ${ }^{1}$ STIE JAYA NEGARA TAMANSISWA MALANG, INDONESIA, E-mail: budisasongkomalang@gmail.com \\ ${ }^{2}$ STIE JAYA NEGARA TAMANSISWA MALANG, INDONESIA, E-mail: enylestariwidarnimalang@gmail.com \\ ${ }^{3}$ STIE JAYA NEGARA TAMANSISWA MALANG, INDONESIA, E-mail: ninobalmy@gmail.com
}

\begin{abstract}
The purpose of this study was to identify the transaction costs of salt farming in Pesanggrahan village, Kwanyar district, Bangkalan district. This study uses a qualitative method to identify the transaction costs of salt farming in Pesanggrahan village, Kwanyar district, Bangkalan district. We found that there are three types of transaction costs in salt cultivation in Pesanggrahan village, Kwanyar district, Bangkalan district, namely asymmetric information, contract costs, and negotiation costs. There are transaction costs in the process of buying and selling salt production between farmers and salt factories. This is identified by the emergence of Asymmetric Information in "Salt Price" and "Making Sorat Jelen" Between Farmers and Salt Factory. Negotiations between Farmers and Se Andi' Sorat (Quantity and Time of Sales) and Se Andi' Sorat with Salt Factory (Quantity and Price of Salt). The Farmer Contract Provisions Must Have Sorat Jelen become a system that makes the transaction costs of salt farmers and salt factories high. Having a travel permit is very difficult for salt farmers, this is because there are several requirements that must be carried out by them. This requirement then led to a contract between the salt farmer and the salt factory.
\end{abstract}

Keywords: Transaction fee; Salt farmer; Bangkalan district.

JEL Classification: G31, L26, P25

Received: June 6, 2021

Accepted: September 29, 2021 


\title{
Coste de Transacción de los Productores de Sal en el Pueblo de Pesanggrahan, Distrito de Kwanyar, Regencia de Bangkalan
}

\author{
BUDI SASONGKO ${ }^{1}$, ENY LESTARI WIDARNI ${ }^{2}$, SURYANING BAWONO ${ }^{3}$ \\ ${ }^{1}$ STIE JAYA NEGARA TAMANSISWA MALANG, INDONESIA, E-mail: budisasongkomalang@gmail.com \\ ${ }^{2}$ STIE JAYA NEGARA TAMANSISWA MALANG, INDONESIA, E-mail: enylestariwidarnimalang@gmail.com \\ ${ }^{3}$ STIE JAYA NEGARA TAMANSISWA MALANG, INDONESIA, E-mail: ninobalmy@gmail.com
}

\begin{abstract}
RESUMEN
El objetivo de este estudio es identificar los costes de transacción del cultivo de la sal en la aldea de Pesanggrahan, distrito de Kwanyar, distrito de Bangkalan. Este estudio utiliza un método cualitativo para identificar los costes de transacción del cultivo de la sal en la aldea de Pesanggrahan, distrito de Kwanyar, distrito de Bangkalan. Encontramos que hay tres tipos de costes de transacción en el cultivo de la sal en la aldea de Pesanggrahan, distrito de Kwanyar, distrito de Bangkalan, a saber, la información asimétrica, los costes de contrato y los costes de negociación. Existen costes de transacción en el proceso de compra y venta de la producción de sal entre los agricultores y las fábricas de sal. Esto se identifica por la aparición de información asimétrica en el "precio de la sal" y la "elaboración de Sorat Jelen" entre los agricultores y la fábrica de sal. Negociaciones entre Agricultores y Se Andi' Sorat (Cantidad y Tiempo de Venta) y Se Andi' Sorat con la Fábrica de Sal (Cantidad y Precio de la Sal). Las disposiciones del contrato de los agricultores deben tener Sorat Jelen se convierten en un sistema que hace que los costes de transacción de los agricultores y las fábricas de sal sean elevados. Tener un permiso de viaje es muy difícil para los salineros, esto se debe a que hay varios requisitos que deben ser llevados a cabo por ellos. Este requisito hace que se establezca un contrato entre el salinero y la fábrica de sal.
\end{abstract}

Palabras clave: Tasa de transacción; Salinero; Distrito de Bangkalan.

Clasificación JEL: G31, L26, P25

Recibido: 06 de Junio de 2021

Aceptado: 29 de Septiembre de 2021 


\section{Introduction}

Every year the domestic demand for salt continues to increase significantly. It was recorded that in 2018 the need for consumption salt and the need for salt for basic production reached 4.2 million tons. The need for salt production reaches 3.7 million tons and the rest is for consumption salt needs. Meanwhile, domestic production has not reached the target, both from salt factories and from salt farmers, which only touched 1.94 million tons so that to meet the remaining salt needs, the Indonesian government had to import from abroad (KKP, 2018). For a more detailed explanation regarding the information on the volume and value of salt imports carried out by the State of Indonesia from 2012-2018, it will be illustrated based on the following graph:

Figure 1.1 Graph of import volume and value from 2012-2018 (Source of BPS and KKP, 2018)

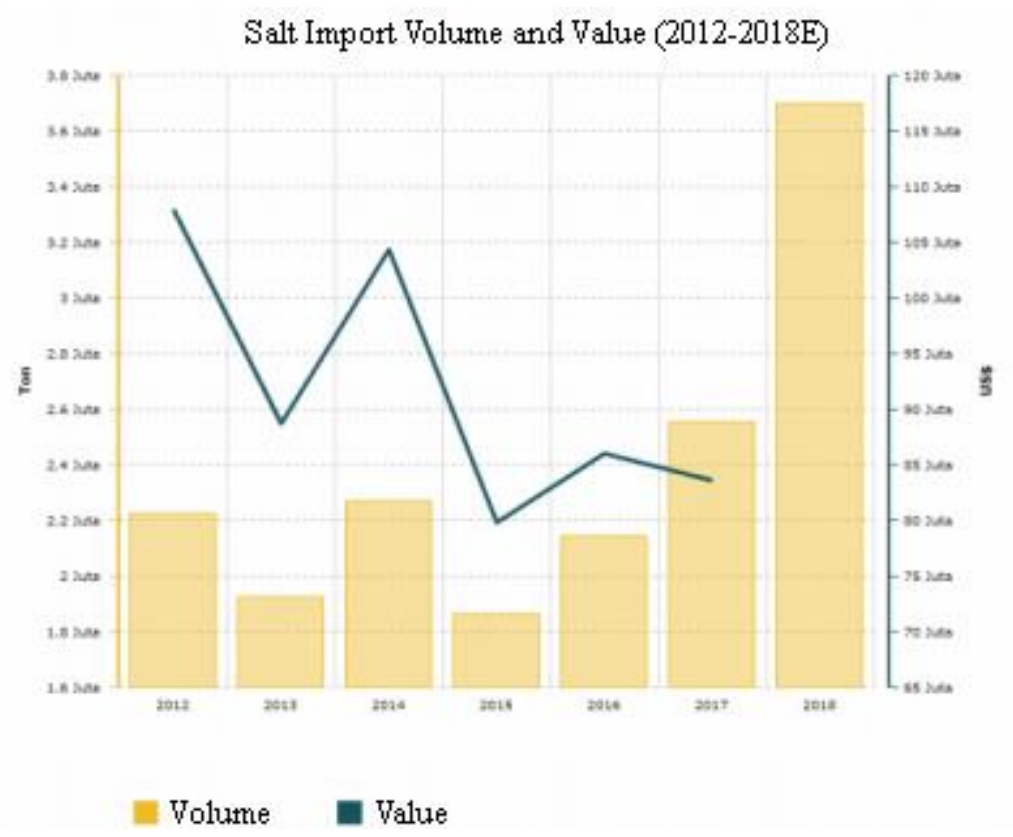

Graph 1.1 above explains that from 2012-2018 the volume and value of salt imports fluctuated. The lowest fluctuation occurred in 2015, while the highest fluctuation occurred in 2018. This shows that the value of salt imports carried out by the government in 2018 was very high compared to previous years. In this way, the demand for salt is high, it is recorded that the region that contributes the largest domestic salt demand comes from East Java reaching 1.1 tons. Meanwhile, Madura, which has the largest salt pond area in East Java, covering 11,113 thousand hectares, is able to produce salt reaching over 1 million tons in 2018 (BPS East Java 2018). The following will explain the total salt production on the island of Madura.

Table 1.1 Total of salt production of each district in Madura 2017-2018

\begin{tabular}{|c|c|c|c|c|c|}
\hline No & Regency & $\mathbf{2 0 1 7}$ & $\mathbf{2 0 1 8}$ & Unit & Land Area (Ha) \\
\hline 11 & Bangkalan & IDR.4.170 & IDR.5.384 & Ton & 178 \\
\hline 22 & Sampang & IDR.200 & IDR.346 & Ton & 3.064 \\
\hline 33 & Pamekasan & IDR. 71 & IDR. 95 & Ton & 913 \\
\hline 44 & Sumenep & IDR. 228 & IDR.235 & Ton & 2.068 \\
\hline 55 & PT. GARAM & IDR. 194 & IDR. 600 & Ton & 5,340 Hektare \\
\hline
\end{tabular}

Source: (BPS for each district, 2018. Processed)

The table above describes the comparison of the total production of each district and PT. GARAM on the island of Madura during the 2017-2018 period based on a count of tons. In the 2018 season, it was seen that all districts experienced a positive trend compared to the previous year, including Bangkalan Regency.

Bangkalan Regency is an area on the westernmost tip of Madura Island which is directly adjacent to the capital city of Surabaya, while the salt pond area in Bangkalan is 178 hectares spread over nine villages in five sub-districts. One of the villages that has the largest salt pond land is located in 
Pesanggrahan Village, Kwanyar District, Bangkalan Regency. The community of Pasanggrahan Village utilizes existing Natural Resources (SDA), one of which is the use of seawater which is processed into salt. Kwanyar Pesanggrahan Village has a salt pond with an area of 28 hectares and the number of salt farmers is 15 people. In the 2018 harvest season, Pesanggrahan Kwanyar Village can produce 1102 tons of salt. The number of residents in Pesanggrahan village with male gender in 2018 was 2565 people, while the number of the female population in 2018 was 2964 people. So the total population is 5,529 people. (BPS Kabupaten Bangkalan. 2018).

The COVID-19 pandemic has had an impact on the economy(Kee et al., 2021). The impact of covid 19 has had an impact on the real business sector (Nair et al., 2021). Salt farmers are often faced with fundamental problems such as how to farm salt in a modern way so as to produce good quality salt, the use of sophisticated technology may also be needed to support success in processing seawater into salt (Silva, Coimbra, Barros, Marriott, \& Rocha, 2015; Spall, Almansi, Huang, Haine, \& Pickart, 2021). However, not a few farmers complain about the cheap salt prices set by the factory (Barbosa et al., 2021; Cui, Sun, Chen, \& Zhang, 2020). This of course cannot be separated from the quality of the salt products produced and government policies which always import from abroad every year, on the pretext that domestic salt production is not able to meet the needs of the Indonesian people, both household needs for consumption and factory needs as basic ingredients production(Ferina, Kresnawati, Susanti, Wagini, \& Fitriano, 2019; Helmi \& Sasaoka, 2018).

The harsh reality that befell salt farmers with low salt prices requires salt farmers to manage as efficiently as possible how to do so in the production process until the sale of their products does not incur too high costs and a long sales flow so as not to experience a difference (loss) between the costs incurred, and income from production (Nirwansyah \& Braun, 2021). In general, the view in NeoClassical economics believes that the market runs perfectly without any costs (costless) because buyers (consumers) have perfect information and sellers (producers) compete with each other so as to produce low prices (Stone, et. Al, 1996). :97; Li,2018). The concept of the market will be able to solve the obstacles that interfere with economic activities with its own strength without the intervention of other parties, it needs a deeper study (Lai, Davies, Chan, Chua, \& Lin, 2020). Mainly, regarding the calculation of the emergence of additional costs (transaction costs) outside of production costs that must be incurred by economic actors each time they carry out their economic activities (Li \& Ito, 2021; Yan \& Lu, 2021).

Madura Island has been a salt-producing area since the Dutch East Indies era where the first area to produce salt was located in Kalianget District, Sumenep. The condition of the land adjacent to the sea makes residents who live in Kalianget Sumenep Madura required to find solutions to improve their standard of living with one of the activities, namely managing seawater into salt. Processing seawater into salt produces different qualities, namely ordinary quality and high quality. The manufacture of low-quality salt does not use a mat or tarpaulin in the pond, while the manufacture of high-quality salt uses a mat or tarpaulin (geomembrane) in the salt pond that. Furthermore, the results obtained also differ between ordinary quality and high quality. High-quality salt is pure white in the form of crystals, while low-quality salt is gray because it directly hits the ground surface. Not only that variable that needs to be explained. The weather factor turned out to be one of the determinants of success in the salt production process. The longer the dry season in an area, the more salt farmers in the region have the opportunity to produce more salt (DKP, Bangkalan Regency 2018).

An institution emerges and develops to minimize transaction costs so as to improve economic performance. The transaction costs include costs for information, negotiation, supervision, coordination, and contract execution. When there is a difference in the level of ownership in transactions, for example, the phenomenon of transaction costs in Bangkalan Madura Regency. There is a factory contract owner who has the right to supply the factory so the farmer must go through the owner of the letter to sell his goods to the factory. The owner of the salt is the farmer and the buyer is the factory because of the owner of the letter, transaction costs occur in the form of transactions between the owner of the letter and the farmer and transaction costs between the owner of the letter and the factory where when there is a transaction with the owner of the letter as 
an intermediary between the salt farmer and the salt factory there are transaction costs in the form of profit mail owner. This makes the factory lose the opportunity to negotiate a lower price with the farmers and the farmer loses the opportunity to make a profit by making direct transactions with the salt factory. Negotiations or bargaining are usually carried out by farmers to get the price they want or the price that is closest to the desired price. In this case, when the bargaining process is felt to be unfinished and the salt farmers are not satisfied with the final decision, then to execute the contract the salt farmers decide to pay the negotiation costs. Then, the negotiation fee is included in the transaction fee.

Contracts or negotiations in Madura by salt farmers create transaction costs. Transaction costs can be interpreted as costs other than production requirements, where information, competition, contract systems, and the buying and selling process can be very asymmetrical. This is what gives rise to transaction costs, which can also be defined as costs for negotiating, measuring, and coercing exchanges. The pre-study indicated the emergence of transaction costs in the salt market in Madura. Of course, transaction costs that arise in the community will affect the independence of salt farmers in carrying out economic activities with the Salt Factory, so a concept of empowerment is needed which in essence emphasizes the autonomy of decision-making from a community group. The existence of salt farmers, salt factories, and owners of contracts with salt factories are different institutions in the form of agents or economic actors in the salt industry in Bangkalan Madura Regency. Of course, this can be understood through institutional economics.

Based on the pre-research conducted in Madura, there is an inefficient transaction system and it continues to this day. Namely, there is an intermediary between the salt factory and the salt farmer. The existence of the contract system does not allow salt farmers to sell their salt directly to the salt factory. This of course increases transaction costs in the form of intermediary profits.

Based on information from one of the informants who is a salt farmer named $\mathrm{H}$. Rasyidi. He revealed that "farmers who are in Pesanggrahan Kwanyar Village after harvesting, the salt is immediately transported and directly delivered to the factory, but yes there are procedures that must be followed" The phenomenon shown by salt farmers in Pesanggrahan Village, Kwanyar District, Bangkalan Regency is quite unique, they are farmers who are able to eliminate the sales channels that are popular in people's salt, namely farmers-middlemen-salt factories or farmersmiddlemen-big traders-factories. On the other hand, if judged from the arguments of salt farmer informants in Pesanggrahan Village which stated that salt farmers cannot sell salt directly to the salt factory but must comply with the procedures set by the factory, the actual institutional design of salt farmers and factories cannot be assessed as effective. and there is an indication of the occurrence of transaction costs in the process.

Eliminating the economics of transaction costs in any economic activity is not an easy matter. The diversity of interests of some parties and the geographical location of a salt production activity makes economic development more complicated. On the other hand, economic actors cannot always depend on other parties so that they get high profits and are independent in running a salt farming business.

If farmers cannot avoid the emergence of transaction costs every time they carry out trading activities with salt factories, this will certainly have a significant impact both in terms of income and on the independence of the farmers. Therefore, one way to overcome these fundamental problems is to apply community development with the concept of empowerment so that a layer of society does not continue to depend on other parties. The concept of empowerment is included in community development and is related to the concepts of self-help, participation, networking, and equity. Research on salt farmers has not touched a deeper level of phenomena such as indications of the emergence of transaction costs and their implications for the independence of salt farmers.

Therefore, researchers feel the need to conduct research related to the identification of transaction costs and their implications for the independence of salt farmers in Pesanggrahan Village, Kwanyar District, Bangkalan Regency. 


\section{Literature Review}

In general, Neo-Classical economics and institutional economics have two different perspectives on the efficiency of economic activity, Neo-Classical believes that markets run perfectly without any costs (costless) because buyers (consumers) have perfect information and sellers (producers) compete with each other so as to produce low prices (Bradley, 2021; Palley, 2017). Opinions expressed by neo-classical about the market running smoothly without the need for any additional costs show that the efficiency measure of economic activity is only based on production costs by eliminating external factors outside of production costs. But in the real world, in fact, there are indications of costs other than production requirements, where information, competition, contract systems, and the buying and selling process can be very asymmetrical. This is what gives rise to transaction costs, which can also be defined as costs for negotiating, measuring, and coercing exchanges (de Frutos \& Gatón, 2021; Lago Peñas, 2021). However, some economists agree that in addition to the costs of producing goods or services, there are additional costs that must be incurred to launch market economic activities which sometimes exceed the cost of production, for example, what is well known in institutional economics is called transaction cost economics. This analytical tool is often used to measure the efficiency of the institutional design (Hadler, 2015). The higher transaction costs that occur in economic activities (transactions), means that the institutional inefficient strategy is designed, and vice versa (Yustika, 2006). In short, the transaction cost theory uses transactions as the basis for the unit of analysis, while the Neo-classical theory uses the product as the basis for the unit of analysis (Greif, 1993).

Economics that is developing in its new branch of new institutional economics sees institutions from the point of view of transaction costs and collective action (Canitez, Çelebi, \& Beyazit, 2019; Prévost \& Rivaud, 2018). Transaction cost analysis includes analysis of ownership and control of natural resources or factors of production (property rights), imbalances in access and control of information (information asymmetry), and opportunistic behavior (Ghosh \& Kathuria, 2015; Liu \& Qin, 2018). This new institutional economics is often referred to as transaction cost economics, while others call it the imperfect information paradigm (Greenwald \& Stiglitz, 1986).

The Old Institutional Economics theory has weaknesses, namely minimal analysis, and no theoretical framework (Sunday, shukor Lim, \& Mazlan, 2021). In their work, they depart from the neoclassical economic tradition and without quantitative theory, so it is not possible to make generalizations that can be derived into policy choices. Neoclassical economics rejects the "working" of Institutional Economics frame work about agents are assumed to operate in a (almost) no action.

Meanwhile, New Institutional Economics emphasized the importance of institutions role in economics development (Bondarenko et al., 2021; Hassan, 2021). The theory states that institutional analysis can use a neoclassical economic framework. However, the assumption that individuals have motif to maximize goals with some constraints remains. Langois (1986:5) views that the problem with the early institutionalist framework is that they want institutions without theory, while Neoclassicalists want economic theory without institutions. While NIE tries to work with both (theories and institutions). From the institutional economic point of view, there are institutions or parties that become economic agents where these economic agents take actions that focus on increasing the profits that can be obtained by themselves. Of course, each party wants the maximum profit. The existence of these parties makes the economy run. However, the motives of the parties or economic agents who want maximum profit often cause transaction costs for producers and consumers. Transaction costs arise when the transaction system is inefficient where there are still intermediaries who should not be needed in the transaction present in the transaction. This increases transaction costs where producers have to miss out on profit opportunities from transactions and consumers can potentially pay more. The amount of the transaction fee is close to the profit earned by the intermediary.

Basically, the difference between the frameworks of the New institutional economists NIE and OIE (in contrast to the Langois view) is not on the condition that one is strict with theory and the other a theory (does not use theory), but each follows a different theoretical agenda (Gui, Diesendorf, \& 
MacGill, 2017; Ménard, 2018). Three basic differences are mentioned by (Peukert, 2001) namely (1) OIE tends to view humans as homo sociologicus while NIE sees humans as homo economicus view. (2) in the analysis carried out, OIE tends to use sociological analysis while NIE explains informal constraints rationally. For example, using invisible hand analysis, opportunity, and transaction costs. (3) The theory and model constructs in OIE tend to be informal, while NIE is more based on Neoclassical economics. However, both have similarities and complement each other (Peukert, 2001). Mirowski (Staveren, 1999) has an interesting view in this regard, namely that writing about institutional economics must be based on theory. Related to this, Staveren (1999) says that institutional economics, especially economic evolution, pays attention (if using a mathematical model) more to dynamic analysis and not to static comparative analysis.

The emphasis on history and context is certainly very difficult when using a mathematical approach. It is possible to explain the multidimensional behavior and attitudes of agents with metaphorical illustrations, and this is of course far from a mathematical model. Based on this argument, the researcher sees the necessity of using sociology (homo sociologicus view) as a perspective to analyze the institution that will be studied in this study. However, not all economists follow homo economicus and not all sociologists use the homo sociologicus model (Kopczewski \& Okhrimenko, 2019). An example in this context is what happens to salt farmers who are about to enter the selling period. If based on economic analysis, the farmer will rationally conduct a sale and purchase transaction of salt, the time of sale, the amount of salt to be sold to the factory in cooperation with other parties or not. However, it's certainly not that simple. Farmers are often faced with the condition that they have no choice. Not infrequently they want to sell their salt production directly to the factory without entering into a contract with another party, but do not have a travel document for that purpose. This limitation brings the consequence of "compulsion" to be trapped in "se andi' sorat". Of course, this phenomenon also cannot be viewed as an economic phenomenon, but it must be explored further what is actually behind the phenomenon.

\section{Methodology}

This study used qualitative research methods. Based on the purpose of this study, namely to identify the transaction costs of salt in Pesanggrahan Village, Kwanyar District, Bangkalan Regency, this research was directed to use qualitative methods with a phenomenological approach. The phenomenological approach was chosen to understand the meaning of an event and the relationships in it in more depth.

This qualitative research was chosen to reveal and understand something behind the phenomenon that is still very abstract and tries to explain in a complex way about research that is difficult to uncover by quantitative methods. In addition, qualitative research can also be interpreted as a research method that seeks to understand more deeply a phenomenon about something related to the research subject which is reflected in behavior, perception, motivation, and action (Moleong \& Edisi, 2004).

The appropriate approach to this research is a phenomenological approach. The phenomenology group emphasizes is the subjective aspect of people's behavior. By using a phenomenological approach, it is hoped that it can assist researchers in conducting deeper research on the research topic.

\section{Results and Discussion}

Salt is a seasonal commodity, large volume with low value (bulky). The salt season usually ranges from 4 to 6 months a year, depending on the length of the dry season. The salt season usually starts from June to November. Farmers carry out salt production activities starting with land processing which lasts approximately 14 days at the beginning of the production season, then the flow of seawater to the salt plot, until the salt process occurs. Next, the farmers do the harvesting, and they are packed into sacks which are usually provided by the collecting traders. Each farmer can produce 
salt with quality KP1, KP2, and KP3. The salt will be transported by truck to processing companies. In carrying out the sales function, farmers as producers.

The salt production process in Pesanggrahan Village relies heavily on sunlight, so the production process only takes place during the dry season, namely from July to November. The technology used is also very simple without a touch of high technology such as windmills and drills to transfer water from one plot to another, cylinders or coils used to harden the salt table, and rakes used in the harvesting process.

The only mechanical device is a diesel engine that farmers use to suck seawater from waterways to enter the reservoir plots. Salt production activities begin by normalizing the channel from the sea, then by using a diesel engine, seawater is drawn to enter the plots. The production process is carried out from generation to generation. The application of new technology such as geomembrane is still felt as not necessary for farmers. The average yield of salt production for 1 ha of arable land produces 1-2 tons per day.

The existence of vacant land which they later turn into salt ponds will help improve the economy of the Pesanggrahan community. Salt production is indeed one of the unique things for Madura because Madura does have the largest potential for salt land in Indonesia, which reaches 15,000 ha. One of the strategic places with potential for salt land is Pesanggrahan Village, Kwanyar.

The technology applied by salt farmers in Pesanggrahan Village, Kwanyar District in producing salt is still very simple, namely using small and medium-sized plots in connection with the water system flowing from the first plot to the next plot. The making of small plots is intended so that evaporation occurs repeatedly. The seawater is channeled into the collecting/settling pond using a windmill and if there is no wind using a bucket.

The price of salt in the Bangkalan Regency tends to vary depending on the weather and salt season. In 2019 the highest salt price was Rp. 35,000 - Rp. 40,000 per sack ( 25 kg content) and Rp. $25,000-\mathrm{Rp} .30,000$ per sack of $25 \mathrm{~kg}$ occurs early in the season, which is the first month or two when salt farmers have little salt from the early harvest. Then the price crawled down to the lowest price, which was Rp. 7.500 - Rp. 12500 per sack or Rp. 300 - Rp. 500 per kg, occurs mid to late season when the salt is already very high at the salt farmer level or at the time of the main harvest.

In general, neo-classical economics and institutional economics have two different perspectives on the efficiency of economic activity, neo-classicalism believes that markets run perfectly without any costs (costless) because buyers (consumers) have perfect information and sellers (producers) compete with each other so as to produce low prices (Stone, et. Al, 1996). Based on the above theory, the buying and selling activities carried out by salt farmers should not incur any costs except the costs that should have been incurred. In addition, they should also have perfect information so that the buying and selling process runs smoothly.

Dorfman, (1981); challen, (2000); quoted by Mburu (2002), explains that transaction costs consist of three categories, namely: (1) search and information costs; (2) negotiation costs (bargaining) and the decision to execute the contract; and (3) costs of monitoring, coercion, and compliance. However, there is no supervision fee in the sale and purchase of salt farmers in Pesanggrahan Village.

Figure 4.1 Transaction Fee Scheme

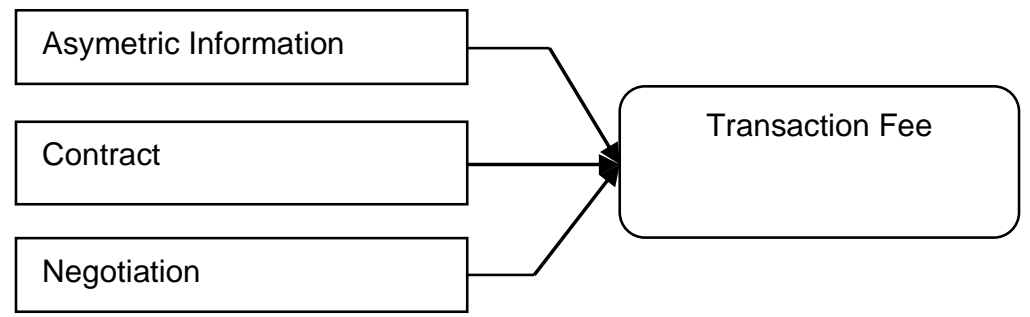

Source: Field Research (2019) 
Prior to the emergence of road permits, salt farmers had carried out a negotiation process beforehand. The negotiation process exists because salt farmers do not have a travel permit, while to be able to sell salt to factories they must have one. Negotiations were initially carried out to get the price of salt according to the market price according to them without knowing whether the information about the market price was asymmetrical or not. Then, the absence of a travel permit made the farmers re-negotiate to determine the cost of a travel permit. In addition, asymetric information also occurs when they want to get information about how to get a travel permit. So there is a contract between the salt factory and the owner of the letter, the salt factory and the salt farmer and the owner of the letter and the salt farmer. In the salt marketing channel in Pesanggrahan Village, there are several factories involved. Usually, salt farmers sell their salt production to factories in Surabaya and Sidoarjo. They do not only deal with one factory because they are worried that the salt will be rejected at the time of sale. So if that happens, they sell to other factories that want to buy their salt production.

The concept of empowerment is included in community development and is related to the concepts of self-help, participation, networking, and equity. The empowerment approach is one of the right methods to reduce or even eliminate transaction costs between salt farmers and salt manufacturers so that salt farmers can get better profits and factories can get salt at a better price because it is directly from the farmers. Empowerment must be able to encourage people to evaluate independently, empowering them to grow independence in setting future steps and opening awareness to choose the right action with confidence in deciding things independently. The absence or lack of transaction costs and asymmetric information in salt buying and selling transactions carried out between farmers and salt factories can benefit both parties.

The salt factory is expected to be a good partner for salt farmers, the provisions that have been made in the application for ownership of road documents that are difficult for salt farmers to fulfill must be reconsidered. In particular, the requirements for farmers such as having to cooperate with a salt factory for many years in order to be able to make travel documents. This of course will greatly help salt farmers to realize group independence, they (farmers) cannot continue to depend on their partners", he said in carrying out economic activities in salt buying and selling transactions with factories. By being a good partnership between salt farmers and salt factories, the salt transaction system between salt farmers and salt factories becomes more efficient. And of course, the efficiency of these transactions benefits salt farmers and salt factories so that they can reduce transaction costs.

The government has the authority to give and decide regulations. In addition, the government can also contribute ideas, facilities, or materials to salt farmers in the process of buying and selling salt production. Things that the government can do, for example, provide training for salt farmers in negotiating, provide facilities for farmers to improve the quality of salt, and provide solutions to problems that are currently happening to salt farmers. So, if this has been done, it is hoped that salt farmers will be independent.

The existence of training on negotiating will increase the knowledge of farmers and hopefully will open their minds about the important role they should have in the buying and selling process. In addition, carrying out an empowerment program is also one way to train salt farmers to be more independent, which is of course under the supervision of the government so that they do it in a focused manner. According to Mr. Edy, one of the supporting informants from the Regency Employee said that:

"Kwanyar is the supplier from Sampang, he doesn't get through because he doesn't have a network with such to the factory directly, so he uses the one from Sampang, he picks it up, and then there's something... ahh, it's just the Sampang supplier who picks up, picks up at the rich Kwanyar location in Tanjung Bumi. Mr. Zaini, so that I don't depend on canoe collectors, that's why I'm applying for a $D O$, just recommending it, maybe ummm, the requirements from the recommendation factory are not emm saying it's feasible to become a supplier, so making it not in the rich office, what kind of a certificate, yes, that's the problem, isn't it like the current condition, actually from the start 
the service really couldn't have a problem with the price, the fishery service couldn't depend on so and so Some are from entrepreneurs, some are so-and-so, what is it from a supplier, it can also be done, we can recommend a letter stating that this is possible, but it all depends on the recommendation, as a condition, it all depends on whether the factory is eligible to be a supplier or not, because it's like Mr. cipto It's been decades, so what, the channel with the factory people, it's been decades, maybe it's been more than twenty years in Kwanyar, right, it's only two thousand and twelve, if the one on the Earth is already tens of years before Kwanyar is far away because it's true, sir. Zaini was the one who pioneered the kwanyar, I don't know why Mr. Zaini was not recommended before, the headmaster also didn't want to sign I don't understand the reason, but the term is not a conditional term.. what is it that determines whether or not to become a supplier, isn't it fixed It's the factor that decides whether or not it's the factory because it's the factor that decides the factory".

Mr. Edy explained that the only way for farmers to be able to directly sell their salt production was to have a travel permit. Meanwhile, to have a travel permit, it is not enough just to have a recommendation letter from the Office, but it takes years for the farmers to build a network with the factory so that the factory feels confident and trusts the salt farmer to be a supplier and has a travel certificate. Because indeed, the decision to issue a travel permit or not depends on the manufacturer's decision. This experience was experienced by one of the salt farmers who, according to Mr. Edy, had met the requirements to make a travel permit. However, the reality is that up to now the farmer has not been able to obtain a travel document, because the factory still has not approved it. Meanwhile, the solution for salt farmers is to improve the quality of salt so that it has good and high quality so that their salt production can be accepted by the factory, by providing facilities and infrastructure or in the form of facilities that can support the activities of farmers. While the solution for the independence of salt farmers is with the knowledge and experience of farmers in salt production, or even in buying and selling transactions, gradually farmers will start to be independent in all things. For travel documents, the government will immediately provide the best solution for them. Independence is not the only hope for the farmers, but there are other hopes that were conveyed by them in the interviews at the time the research was conducted. The salt farmers delivered it with hope. Hope that their hopes can reach the government and the factory.

\section{Conclusion}

Based on the results of research conducted at the research location It can be concluded that there are three types of transaction costs in salt cultivation in Pesanggrahan village, Kwanyar district, Bangkalan district, namely asymmetric information, contract costs, and negotiation costs. There are transaction costs in the process of buying and selling salt production between farmers and salt factories. This is identified by the emergence of Asymmetric Information in "Salt Price" and "Making Sorat Jelen" Between Farmers and Salt Factory. Negotiations between Farmers and Se Andi' Sorat (Quantity and Time of Sales) and Se Andi' Sorat with Salt Factory (Quantity and Price of Salt). The Farmer Contract Provisions Must Have Sorat Jelen become a system that makes the transaction costs of salt farmers and salt factories high. Having a travel permit is very difficult for salt farmers, this is because there are several requirements that must be carried out by them. This requirement then led to a contract between the salt farmer and the salt factory. The existence of transaction costs causes farmers to have a dependence on se andi' sorat or the owner of a contract with the factory. And they also have to pay it every time they make a sale and purchase transaction. As a result, salt farmers in Pesanggrahan Village cannot be independent. They cannot sell their salt production directly to the factory. The dependence of salt farmers on se andi' sorat shows that in fact independence has not been fully realized. Circumstances that force salt farmers to always depend on se andi' sorat, make them unable to develop. 


\section{References}

1. Barbosa, C. M., Kenup-Hernandes, H. O., Raitz, C., Dam, R. S. de F., Salgado, W. L., Lima, I. C. B., ... Salgado, C. M. (2021). Development of a non-invasive method for monitoring variations in salt concentrations of seawater using nuclear technique and Monte Carlo simulation. Applied Radiation and Isotopes, 174, 109784.

2. Bondarenko, O., Kovalchuk, S., Rodionov, S., Miroshnik, M., Kitchenko, O. M., \& Franchuk, L. (2021). Improving Approaches to the Formation of Enterprise's Marketing Budgets.

3. Bradley, P. (2021). An Institutional Economics Framework to Explore Sustainable Production and Consumption. Sustainable Production and Consumption, 27, 1317-1339.

4. Canitez, F., Çelebi, D., \& Beyazit, E. (2019). Establishing a metropolitan transport authority in Istanbul: A new institutional economics framework for institutional change in urban transport. Case Studies on Transport Policy, 7(3), 562-573.

5. Cui, J., Sun, T., Chen, L., \& Zhang, W. (2020). Engineering salt tolerance of photosynthetic cyanobacteria for seawater utilization. Biotechnology Advances, 43, 107578.

6. de Frutos, J., \& Gatón, V. (2021). A pseudospectral method for option pricing with transaction costs under exponential utility. Journal of Computational and Applied Mathematics, 394, 113541.

7. Ferina, Z. I., Kresnawati, K., Susanti, N., Wagini, W., \& Fitriano, Y. (2019). Peningkatan Kesejahteraan Masyarakat Melalui Pengembangan Potensi Lokal Di Desa Sukasari Kecamatan Periukan Kabupaten Seluma Provinsi Bengkulu. Jurnal Pengabdian Masyarakat Bumi Raflesia, 2(1).

8. Ghosh, R., \& Kathuria, V. (2015). Gas based power generation in India: lessons from a transaction cost analysis. Energy Strategy Reviews, 8, 1-7.

9. Greenwald, B. C., \& Stiglitz, J. E. (1986). Externalities in economies with imperfect information and incomplete markets. The Quarterly Journal of Economics, 101(2), 229-264.

10.Greif, A. (1993). Contract enforceability and economic institutions in early trade: The Maghribi traders' coalition. The American Economic Review, 525-548.

11.Gui, E. M., Diesendorf, M., \& MacGill, I. (2017). Distributed energy infrastructure paradigm: Community microgrids in a new institutional economics context. Renewable and Sustainable Energy Reviews, 72, 1355-1365.

12.Hadler, M. (2015). Institutionalism and Neo-institutionalism: History of the Concepts. In International encyclopedia of the social and behavioral sciences (pp. 186-189). Elsevier.

13. Hassan, A. S. (2021). Foreign aid and economic growth in Nigeria: The role of institutional quality. Studies of Applied Economics, 39(3).

14.Helmi, A., \& Sasaoka, M. (2018). Dealing with socioeconomic and climate-related uncertainty in small-scale salt producers in rural Sampang, Indonesia. Journal of Rural Studies, 59, 88-97.

15.Kee, D. M. H., Hisam, N. N. B. N., Abd Rashid, N. H. B., Aziz, N. S. B. A., Mazlan, N. A. B., \& Mahadi, N. A. Z. B. (2021). The Impact of Using Cashless Payment during the Covid-19 Pandemic: A Case Study of Maybank. International Journal of Accounting \& Finance in Asia Pasific (IJAFAP), 4(2), 107-117.

16.Kopczewski, T., \& Okhrimenko, I. (2019). Can homo economicus be an altruist? A classroom experimental method. International Review of Economics Education, 32, 100167.

17.Lago Peñas, I. (2021). Transaction costs in electoral coordination: how turnout shapes changes in the number of parties. Electoral Studies. 2021 May 18; 72: 102349.

18.Lai, L. W. C., Davies, S. N. G., Chan, E. H. W., Chua, M. H., \& Lin, C. L. (2020). The production and consumption of land use planning: A neo-institutional economic perspective \& three Taiwan case studies of planning layering. Land Use Policy, 99, 104910. 
19.Li, X., \& Ito, J. (2021). An empirical study of land rental development in rural Gansu, China: The role of agricultural cooperatives and transaction costs. Land Use Policy, 109, 105621.

20.Liu, J., \& Qin, T. (2018). A comparative analysis of fishing rights from a transaction cost perspective. Ecological Economics, 153, 89-99.

21.Ménard, C. (2018). Research frontiers of new institutional economics 弥. RAUSP Management Journal, 53, 3-10.

22.Moleong, L. J., \& Edisi, P. (2004). Metodelogi penelitian. Bandung: Penerbit Remaja Rosdakarya.

23.Nair, R. K., Reddy, L. S., Verma, P., Pandey, R., Yuwono, S., Sin, L. G., ... Ing, T. W. S. (2021). The Impact of COVID 19 Towards International Business Strategy: A study of Coca-Cola Company. International Journal of Accounting \& Finance in Asia Pasific (IJAFAP), 4(2), 73-92.

24.Nirwansyah, A. W., \& Braun, B. (2021). Assessing the degree of tidal flood damage to salt harvesting landscape using synthetic approach and GIS-Case study: Cirebon, West Java. International Journal of Disaster Risk Reduction, 55, 102099.

25.Palley, T. (2017). The General Theory at 80: Reflections on the history and enduring relevance of Keynes' economics. Investigación Económica, 76(301), 87-101.

26.Peukert, H. (2001). Bridging old and new institutional economics: Gustav Schmoller and Douglass C. North, seen with oldinstitutionalists' eyes. European Journal of Law and Economics, 11(2), 91130.

27.Prévost, B., \& Rivaud, A. (2018). The World Bank's environmental strategies: Assessing the influence of a biased use of New Institutional Economics on legal issues. Ecosystem Services, 29, 370-380.

28.Silva, I., Coimbra, M. A., Barros, A. S., Marriott, P. J., \& Rocha, S. M. (2015). Can volatile organic compounds be markers of sea salt? Food Chemistry, 169, 102-113.

29.Spall, M. A., Almansi, M., Huang, J., Haine, T. W. N., \& Pickart, R. S. (2021). Lateral redistribution of heat and salt in the Nordic Seas. Progress in Oceanography, 102609.

30.Staveren, I. van. (1999). Chaos theory and institutional economics: Metaphor or model? Journal of Economic Issues, 33(1), 141-167.

31.Sunday, D., shukor Lim, N. H. A., \& Mazlan, A. N. (2021). Sustainable Affordable Housing Strategies For Solving Low-Income Earners Housing Challenges In Nigeria. Studies of Applied Economics, 39(4).

32.Yan, D., \& Lu, X. (2021). Utility-indifference pricing of European options with proportional transaction costs. Journal of Computational and Applied Mathematics, 397, 113639.

33.Yustika, A. E. (2006). Ekonomi Kelembagaan: definisi, teori, dan strategi. Malang: Bayumedia Publishing. 